University of Nebraska - Lincoln

DigitalCommons@University of Nebraska - Lincoln

\title{
Adult dispersal of Ostrinia nubilalis Hübner (Lepidoptera: Crambidae) and its implications for resistance management in Bt- maize
}

J. A. Qureshi

Kansas State University, jawwadq@ufl.edu

L. L. Buschman

Kansas State University, Ibuschma@ksu.edu

James E. Throne

USDA-ARS, Manhattan, KS, james.throne@ars.usda.gov

S. B. Ramaswamy

Kansas State University

Follow this and additional works at: https://digitalcommons.unl.edu/usdaarsfacpub

Part of the Entomology Commons, and the Genetics and Genomics Commons

Qureshi, J. A.; Buschman, L. L.; Throne, James E.; and Ramaswamy, S. B., "Adult dispersal of Ostrinia nubilalis Hübner (Lepidoptera: Crambidae) and its implications for resistance management in Bt-maize" (2005). Publications from USDA-ARS / UNL Faculty. 1442.

https://digitalcommons.unl.edu/usdaarsfacpub/1442

This Article is brought to you for free and open access by the U.S. Department of Agriculture: Agricultural Research Service, Lincoln, Nebraska at DigitalCommons@University of Nebraska - Lincoln. It has been accepted for inclusion in Publications from USDA-ARS / UNL Faculty by an authorized administrator of DigitalCommons@University of Nebraska - Lincoln. 


\title{
Adult dispersal of Ostrinia nubilalis Hübner (Lepidoptera: Crambidae) and its implications for resistance management in Bt-maize
}

\author{
J. A. Qureshi ${ }^{1,2, *}$, L. L. Buschman ${ }^{1,2}$, J. E. Throne ${ }^{1,3}$ and S. B. Ramaswamy ${ }^{1}$ \\ ${ }^{1}$ Department of Entomology, Kansas State University, Manhattan, KS, USA; ${ }^{2}$ K-State University Southwest \\ Research and Extension Center, Garden City, KS, USA; ${ }^{3}$ USDA-ARS Grain Marketing and Production \\ Research Center, Manhattan, KS, USA
}

Ms. received: December 20, 2004; accepted: May 3, 2005

\begin{abstract}
Dispersal of European corn borer, Ostrinia nubilalis Hübner was examined by release and recapture of the dye marked adults and by capture of the feral adults in and around the large 50 ha center pivot irrigated fields of Bacillus thuringiensis (Bt) maize. Pheromone and black light traps were used to catch the adults. In 1999, 15094 marked males and 7993 marked females were released, and in 2001, 13942 marked males and 9977 marked females were released. In 1999, maximum mean recapture beyond the release point was 1.95 and $1.67 \%$ for males and females, but in 2001, the recapture rate was 9.97 and $4.37 \%$ for males and females. Few males $(3.8 \%)$ and females $(2.07 \%)$ were recaptured in neighbourhood maize fields. An exponential decay function explained recapture of marked adults across the dispersal distance. More than $90 \%$ of marked adults were recaptured within $300 \mathrm{~m}$ of the release point. Large numbers of feral adults were captured throughout the study fields. Feral adult dispersal could be fitted to a linear model. Virgin females (20\% marked and $8 \%$ feral) were captured throughout the study fields. The recapture of marked insects suggests that the dispersal was limited. However, capture of feral adults throughout Bt-maize fields indicate that the actual dispersal may be more extensive than indicated by recapture of marked adults. Potential refuge sources for the feral adults were $587-1387 \mathrm{~m}$ from the edge of the study fields. It is not clear if the dispersal recorded in this study is extensive enough to support the current resistance management strategy for corn borers. There appears to be some dispersal of corn borers from the non-transgenic 'refuge' fields into the transgenic fields that allows some genetic mixing of the two populations.
\end{abstract}

Key words: Bt-corn, Bt-maize, European corn borer, insect behaviour, pest management, transgenic crops

\section{Introduction}

Understanding the dispersal behaviour of highly mobile pest insects is important to explain their biology and ecology and in developing effective pest management strategies (Turchin and ThOENy, 1993). In addition, information on the dispersal behaviour of pests targeted by transgenic crops is needed to develop models that can be used to forecast the potential evolution of pest resistance to transgenic crops. Transgenic crops currently provide excellent control of target pests, but there is concern that the pests will develop resistance (or virulence) to this trait. There is no empirical basis on which to judge their durability and, thus, theoretical population and genetic models have been used to forecast the

*Current address: K-State University Agricultural Research CenterHays, 1232-240th Avenue, Hays, KS 67601-9228, USA. development of resistance in these pests. These models include many assumptions about biological parameters such as dispersal (Gould, 1994). Some models for development of resistance in European corn borer against transgenic maize appear to be sensitive to the dispersal parameters used (GuSE et al., 2002; ONSTAD et al., 2002). Therefore it would be useful to have a better understanding of the dispersal behaviour of this pest.

European corn borer, Ostrinia nubilalis (Hübner), is an important economic pest of maize, Zea mays L., in North America and Europe. In North America damage and control costs exceed $\$ 1$ billion per year (MAson et al., 1996; CAlvin and VAn Duyn, 1999). European corn borer has become a primary target of transgenic Bacillus thuringiensis maize (Bt-maize) hybrids (KozIEL et al., 1993; OstuIE et al., 1997). The Bt-maize is extremely effective in controlling European corn borer (OstLIE et al., 1997). However, there is concern that Bt-maize acreage will continue to 
increase and that the European corn borer could develop resistance to the insecticidal protein expressed in Bt-maize plants (OstLIE et al., 1997). The selection pressure on target pest populations is higher for Bt-maize than it is for most chemical insecticides, because the toxin is present continuously throughout the growing season. This means that the chances of developing resistance are high, and resistance could develop quickly.

Laboratory selected strains of European corn borer have developed moderate levels of resistance to $\mathrm{Bt}$ proteins incorporated in meridic diet (HuANG et al., 1999). This suggests that some forms of resistance could be present in field populations, and the success of Bt-maize could be short lived if European corn borer develops resistance to Bt-maize (OstLIE et al., 1997). The Environmental Protection Agency (EPA) of the United States has addressed this concern by requiring seed companies to develop and implement a resistance management plan (OsTLIE et al., 1997; US EPA, 2001). They have mandated the use of the High Dose/Refuge Strategy as a prophylactic insect resistance management (IRM) plan (OstLIE et al., 1997; US EPA, 1998; Shelton et al., 2000). This strategy includes two components: high dose Bt plants to kill all susceptible homozygotes (SS) and most or all heterozygotes (RS) for a resistance allele, together with the planting of a susceptible maize crop (a refuge) to produce $\mathrm{SS}$ insects to mate with any $\mathrm{RR}$ or $\mathrm{RS}$ insects that might develop in the Bt-maize field. As long as the resistance gene frequency is low and resistance is inherited as a recessive trait, all resulting offspring (SS or RS) should be susceptible to the high dose Bt-maize plants. For this strategy to work, the adult insects must be able to disperse from the non-Bt 'refuge' field into the Bt-maize field to facilitate mating between susceptible and potentially resistant populations (Gould, 1994; Ostlie et al., 1997; Shelton et al., 2000).

European corn borer dispersal has been evaluated in Iowa and Nebraska (Hunt et al., 2001; SHowers et al., 2001). Most of the work from Iowa suggests that there is extensive long distance dispersal and that random dispersal is a reasonable assumption for modelling the European corn borer. Marked adults were recovered 23-49 km from the release point (SHOwERs et al., 2001). According to this 'general model' of European corn borer dispersal (SHOwERs et al., 1980), adults leave the maize field after emergence to seek out 'action sites' (dense, grassy patches in fence rows or field margins) outside the field where they spend time and mate. Females fly back into maize fields to oviposit. In contrast, in northeastern Nebraska marked adults released in furrow-irrigated maize tended to remain in or near the irrigated maize (Hunt et al., 2001). When they were released at the field edge, neither males nor females displayed any tendency to move out of the irrigated maize into the mixed grasses found along the field edges as suggested by the general model of dispersal. In Alberta, Canada, few adults were found in action sites outside the irrigated maize fields, but they appeared to remain inside the irrigated maize field (LEE, 1988). Thus, the dispersal behaviour appears to be different in irrigated compared with that in dryland maize fields.

A number of workers have described changes in European corn borer dispersal and mating activity under different environmental conditions. For example, high densities of European corn borer were associated with damp ground and the presence of dew or free water (Derozari et al., 1977). Female calling activity was reported to begin earlier and last longer under high-humidity compared with low humidity conditions (WEBSTER and CARDÉ, 1982; RoYER and McNeIL, 1991). Mating success was also reported to be higher under high humidity conditions (SPARKS, 1963; RoYer and MCNeIL, 1991). Increased flight activity was observed under high humidity conditions (SHOwers et al., 1974).

Since environmental conditions are very different across the European corn borer range it is likely that its dispersal will be different across this range. This means that there is no uniform assumption of extensive and completely random dispersal that can be used in IRM models (GuSE et al., 2002; ONSTAD et al., 2002) that would be valid across these situations. These changes in dispersal behaviour could impact IRM, because reduced or enhanced dispersal could significantly affect the evolution of resistance in European corn borer against Bt-maize.

In Western Kansas, maize is commonly grown in large irrigated fields (often under a center pivot irrigation systems) and European corn borer action sites are seldom observed outside of maize fields (LLB, personal observation). Therefore, the current experiments were conducted to study dispersal of European corn borer adults in Western Kansas where maize is grown under irrigation in a semi-arid climate. Markrelease-recapture techniques were used together with the capture of feral adults to evaluate European corn borer dispersal.

\section{Materials and Methods}

The European corn borers used in these mark-release-recapture experiments were reared at the USDA-ARS Corn Insects and Crop Genetics Research Unit, Ames, IA, and shipped as pupae to Garden City, KS. The source colonies were established each summer from feral larvae collected in Iowa maize fields. These insects would be the $Z$-type European corn borers, which are found on maize throughout central North America (MAson et al., 1996). The insects were reared on a standard meridic diet (LewIS and LyNCH, 1969). The reared insects were marked by incorporating oil-soluble dyes [Sudan Red 7B (C.I. 26050) and Sudan Blue 670 (C.I. 61554), SigmaAldrich, Milwaukee, WI, USA] in the diet (Hunt et al., 2000).

Study fields were selected that did not have corn borer infested stubble from the previous year in order to avoid production of feral adults. The 1999 study fields had Bt-maize stubble and the 2001 study field had winter wheat stubble. The fields were planted to Bt-maize (Yieldgard ${ }^{\mathrm{TM}}$, $1999=$ Northrup King (now Syngenta Seeds Inc., Minneapolis, Minnesota, USA); 2001 = Pioneer Hi-Bred International Inc., Johnson, Iowa, USA) to eliminate production of feral adults within the field, to reduce the number of trapped adults, and to collect data on feral adults that dispersed into the study fields. 


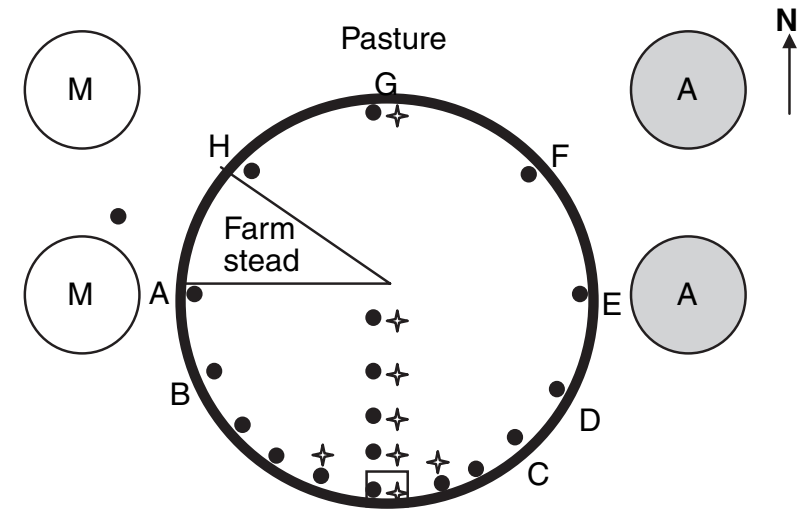

1999 North field, Bt-maize 1998-1999

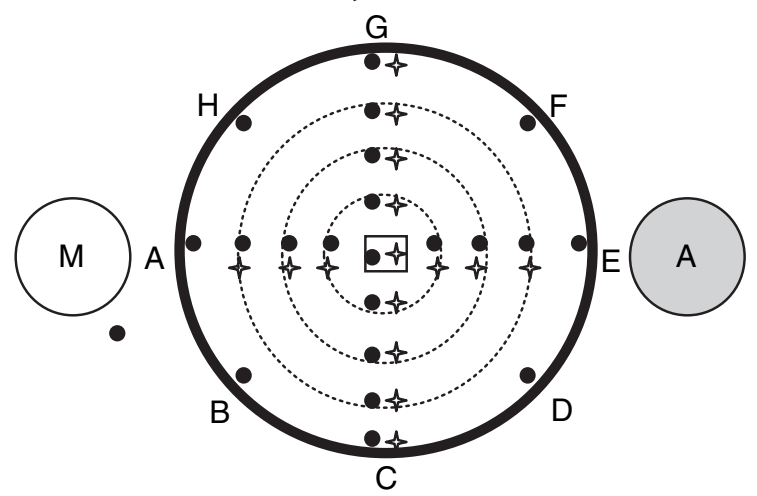

1999 South field, Bt-maize 1998-1999

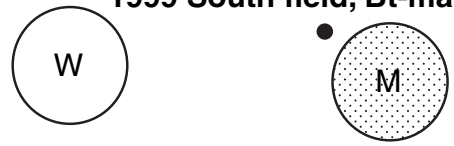

Pasture

Fig. 1. Schematic representation of traps at locations in and around 1999 study fields ( $\square$, release point; pheromone trap; $\star$, light trap) and the crop circles in the immediate neighbourhood of study fields. Circle letter $=1998$ crop $(M$, maize; $W$, wheat; A, Alfalfa $)$, Circle background $=1999$ crop (O, Maize; $\oplus$, Wheat; - Alfalfa). Neighbourhood fields are not drawn to same scale as study field. They were similar to the study field in size. The letters $A-H$ represent the perimeter traps on each transect

\subsection{Experiments}

Two neighbouring ( $5 \mathrm{~m}$ apart) center pivot irrigated circles of Bt-maize were located $12 \mathrm{~km}$ southeast of Garden City, Kansas (N37, E101), and will be referred as north field (ca. $44 \mathrm{ha}$ ) and south field (ca. $50 \mathrm{ha}$ ) (fig. 1). A small nursery of non-Bt-maize ( $0.2 \mathrm{ha}$ ) was planted at the release site in each field to rear corn borers on plants treated with $\mathrm{RbCl}$ and $\mathrm{CsCl}$ for a companion dispersal study using these elemental markers. However, the intended $\mathrm{RbCl}$ and $\mathrm{CsCl}$ treatments and corn borer inoculations did not occur. Since the plants were exposed to first generation released and feral moths there could have been a few feral adults produced in this nursery. However, we did not find corn borer infested plants and there was no increase in the catch of feral insects in the traps near the release site. The release site for the south field was located in the center of the field, but the release site for the north field was along the south margin of the field near the south field (fig. 1).

The neighbourhood of the two study fields is illustrated in fig. 1. The corners beyond the reach of the center pivot sprinklers were in fallow wheat stubble with very few weeds.
There were four non-Bt-maize fields to the west of the study fields and a field of maize stubble to the south that were potential sources of first and second-generation feral European corn borer adults. There were no other maize fields within several miles to the north and east, but there were other maize fields scattered to the west. The non-Bt-maize fields were sprayed with insecticides to control secondgeneration corn borers, but the study fields were not sprayed.

The two test fields were planted at the same time, but the south part of the north field needed to be replanted about a month later, and development of that maize was considerably later than that of the rest of the study fields. The first planting in both fields was at the 12- to 14-leaf stage (ca. $60 \mathrm{~cm}$ high) during the first generation flight of feral adults, while the replanted maize was at the two-leaf stage. The first planting in both fields was in the 14- to 18-leaf stage $(64-120 \mathrm{~cm}$ high) during the first release of marked adults, while the replanted maize was at the 6- to 10-leaf stage. A severe hailstorm on 1 July caused serious plant and trap damage that terminated recapture of the first release. The north half of the north field was abandoned due to the hail damage. The first planting was at the silking stage during the second release of marked adults, while the replanted maize was at the 18-leaf to tassel stage.

The pupae for the first release were placed in the field on 22 June, just after the first generation flight of feral adults. There were ca. 8288 blue pupae for the north field, and ca. 7187 red pupae for the south field. The first release was in the field for 9 days before it was terminated by the hailstorm. The pupae for the second release were placed in the field on 13 July, just before the second flight of feral adults. The second release contained ca. 7348 blue pupae for the north field and ca. 6372 red pupae for the south field. The second release was in the field for 24 days.

During the first generation flight of feral adults there were eight pheromone traps installed at sites $\mathrm{A}-\mathrm{H}$ around the perimeter of each field (fig. 1). During the first release of marked European corn borer, additional traps were installed in transects on the north south and east west transects (fig. 1). European corn borer pheromone traps were installed at all trapping sites, whereas black light traps were installed only on the north south transect. The black light and pheromone traps were installed $2 \mathrm{~m}$ apart but equidistant from the release site. During the second release of marked European corn borer, additional traps were installed on the east west transect and three pheromone traps were installed outside the study fields near non-Bt-maize fields that were potential sources of feral adults (fig. 1). A European corn borer pheromone trap and a black light trap were installed at each release point to record the emergence pattern and to calculate the dispersing proportions of males and females. During the first release of marked adults there were 18 and 21 ECB pheromone traps and six and nine black light traps installed in the north and south fields, respectively. In the north field perimeter traps $\mathrm{A}-\mathrm{H}$ were installed at 550, 274, $60,366,610,732,762$ and $732 \mathrm{~m}$ from the release point, respectively (fig. 1). In the south field traps were installed at $30,61,152$ and $366 \mathrm{~m}$ on the north, south, east and west transects from the release point (fig. 1). The perimeter traps A-H were installed between 366 and $396 \mathrm{~m}$ from the release point. During the second release of marked adults and second-generation flight of feral adults, there were a total 18 and 21 pheromone traps and 7 and 15 black light traps installed in the north and south fields, respectively.

\subsection{Experiments}

A center pivot irrigated circle of Bt-maize (ca. 50 ha) was located $16 \mathrm{~km}$ southwest of Garden City, Kansas (N37, 


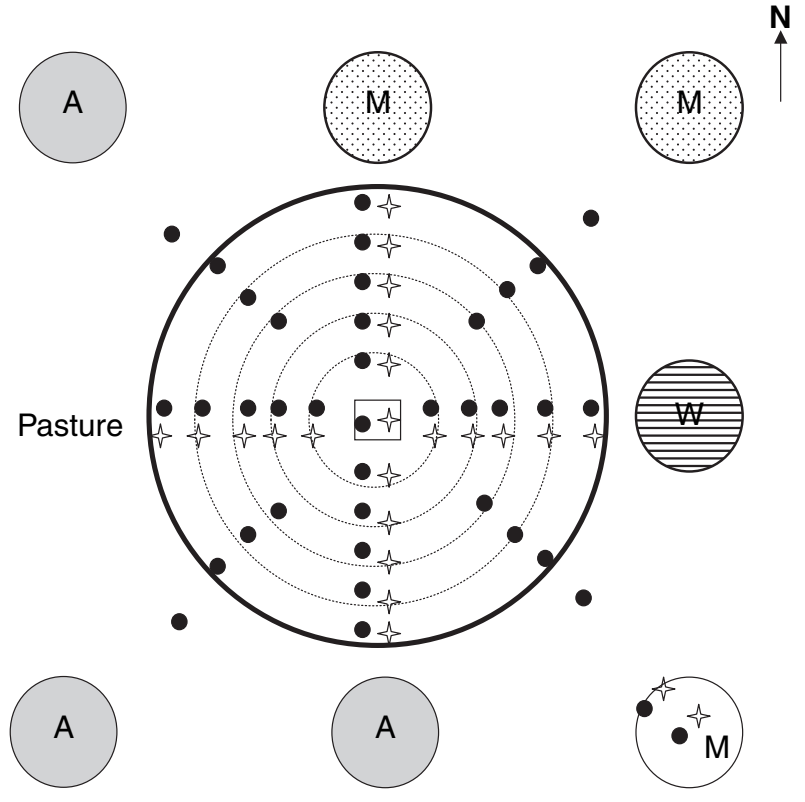

2001 Field, Bt-Maize 2000-2001

Fig. 2. Schematic representation of traps at locations in and around 2001 study field ( $\square$, release point; pheromone trap; $\star$, light trap) and the crop circles in the immediate neighbourhood of study field. Circle letter $=2000 \mathrm{crop}(M$, maize; $W$, wheat; A, Alfalfa $)$, Circle background $=2001$ crop ( $\odot$, Maize; $\Phi$, Wheat; - Alfalfa; $\ominus$, Potato). Neighbourhood fields are not drawn to same scale as study field. They were similar to the study field in size

E101) (fig. 2) that was planted to a Yieldgard ${ }^{\mathrm{TM}}$ Bt-maize hybrid on 25 April. The field had been in winter wheat and grazed out before maize was planted. A small nursery of nonBt-maize $(0.2$ ha) was planted at the release site to rear corn borers on plants treated with $\mathrm{RbCl}$ and $\mathrm{CsCl}$ for a companion dispersal study using elemental markers. These corn borers went into diapause and did not emerge during the second flight as intended. There was no concentration of unmarked adults in the traps near the nursery site so there was no evidence that feral European corn borers were produced in the nursery site. The neighbourhood of the study field is illustrated in fig. 2. The corners beyond the reach of the center pivot sprinklers remained in native sand hill vegetation (grass and sagebrush). The surrounding fields were wheat, potato, alfalfa, maize and native grass pasture. The only known non-Bt-maize field was located ca. $0.2 \mathrm{~km}$ to the southeast of the study field. The non-Bt-maize fields in the neighbourhood may have been sprayed with insecticides to control corn borers, but the study field was not sprayed.

The release site was located in the center of the field (fig. 2). The European corn borer pupae marked with red dye were taken to the field for three releases, ca. 13920 on 17 June, ca. 12052 on 11 July, and ca. 9360 on 5 August. Each release lasted for 18 days. The first release of 17 June occurred just after the peak of the first generation flight of feral adults. The second release of 11 July occurred at the beginning of the second-generation flight of feral adults. The third release of 5 August occurred just after the secondgeneration flight of feral adults.

There were 21 black light and 21-33 pheromone traps installed inside the study field. The traps were installed at 15 ,
46, 107, 229 and $366 \mathrm{~m}$ on the north, south, east and west transects from the release point (fig. 2). European corn borer pheromone traps were installed at all trapping sites, whereas black light traps were installed on the north south and east west transects. The black light traps were installed $2 \mathrm{~m}$ from the pheromone traps, but equidistant from the release site. One pheromone and one black light trap were installed at the release point. The traps on the north, south, east and west transects were installed at specified distances from the release site (fig. 2). Only pheromone traps were installed on the diagonal transects at 107, 229 and $366 \mathrm{~m}$ from the release point, respectively (fig. 2). The perimeter traps were $6-15 \mathrm{~m}$ from the field edge. There were also four trapping sites outside the study field over the native sand hill vegetation and two in the non-Bt-maize field to the southeast that was a potential source of feral European corn borer (fig. 2). One temperature and humidity sensor (Hobo Pro, Onset Computer Co., Bourne, MA) was installed near the release site and at each of the eight trap locations on the perimeter of the field.

Dye-marked European corn borer pupae were placed in five-gal plastic buckets with a wet sponge added to maintain humidity. The buckets were covered with corrugated roofing steel to protect pupae from rain and irrigation, but allow the adults to emerge and disperse as they enclosed. The buckets were placed at release sites usually near the center of the circular study fields. Pupae were placed in the field instead of releasing caged adults to avoid unnatural interactions of large numbers of adults being released at the same time.

Marked and feral European corn borer adults were captured using two types of traps: Ellisco-type battery operated black light traps (15 W) (Gemplers, Bellville, WI) and $90 \mathrm{~cm}$ diameter metal screen Hartstack cone traps baited with European corn borer (Iowa) pheromone lures (Trécé supplied by Gimplers, Bellville, WI). A DDVP Vaportape II (Gemplers, Bellville, WI) was added to the black light trap bucket to kill insets that fell into it. The European corn borer adults remained alive in the pheromone traps and were anesthetized with ether (automotive starter fluid) so they could be counted and examined for marker. Pheromone lures were replaced every 14 days. Bulbs in the black light traps were replaced as needed. The pheromone traps captured males only, whereas black light traps captured both the males and females. The traps were monitored daily during feral adult flights or marked adult releases. Adults captured at each location were counted and identified as marked or unmarked. This was done in the field when possible or the adults were placed in resealable plastic bags labelled for each location and taken to the laboratory and refrigerated until they could be identified and recorded. In both years all marked females were dissected in the laboratory to determine mating status based on the presence or absence of a spermatophore in the bursa copulatrix. In 2001 most of the feral females captured before 25 July were dissected to determine mating status. After that date the numbers of females captured was too large to keep up with dissections.

\subsection{Data analysis}

For each release, the number of adults that emerged from each pupal ring was estimated by dissecting one-fourth of each ring to count intact and empty pupal cases after each release. A sample of 150 adults was examined to determine the sex ratio, and that ratio was used to estimate the number of males and females from the number that emerged from pupae. Dead adults in the buckets were counted and subtracted from the estimated numbers of emerged adults to obtain the number that dispersed from the bucket. The 
number captured at the release site was subtracted from the number that dispersed from the bucket to determine the number that dispersed beyond the release point.

We used TableCurve 2D to fit an equation to the marked and feral capture data from traps along the four major transects (north, south, east and west) across dispersal distance (Jandel Scientific, 1996). Table Curve 2D automatically fits several thousand families of equations to the data (Systat Software Inc., 2002). We selected equations that best described the data based on the magnitude and pattern of residuals, lack-of-fit tests, and whether the equations were biologically reasonable for describing the data.

Numbers of adults caught in each trap were summed over time for each release or generation. The recaptured numbers of marked adults in the first release of the 1999 south field, and in each release of the 2001 field, were examined across dispersal distance from the release point to the perimeter traps. Only the combined recapture of marked males and females in the light traps was tested for the 1999 south field. Each release of 2001 contained five data variables: males recaptured in pheromone traps, males recaptured in light traps, females recaptured in light traps, combined males and females recaptured in light traps, and combined males and females recaptured for pheromone and light traps. The capture of feral adults in first generation flight (2001 field) and second-generation flight (1999 south field, 2001 field) were also tested for best fit with dispersal distance from the perimeter trap 'as zero distance' to the field center 'release point of marked insects'. The feral captures were also tested for the five data variables as described above for the marked recaptured adults.

The model equations $\left(\hat{y}=a+b e^{-x}\right.$ and $\hat{y}=a /$ $\left.\left(1+2 a^{2} b x\right)^{0.5}\right)$ for mark-recapture data were integrated and the integrals were solved for a number of distances $(x)$ between 0 and $366 \mathrm{~m}$ to determine the area under the curve corresponding to the distances within which 50, 90, 95 and $99 \%$ of the dispersed insects would be found. The slope and intercept values of model equations for particular data sets were used to calculate the estimated dispersal ranges.

The 1999 (second-generation flight south field) and 2001 data from pheromone and light trap catches on the main transects were tested for normality using Shapiro-Wilk test, and then analysed for male catch difference using a paired $t$-test (SNEDECOR and Cochran, 1989) in SAS (SAS Institute, 1999-2000). Data with non-normal distributions were analysed using Wilcoxon Signed Rank test (SNEDECOR and Cochran, 1989). The 2001 data from pheromone traps on the main transects (installed near light traps) were compared with data from pheromone traps on transects without light traps to evaluate potential differences in male catches due to presence of the light trap. Only the traps installed at 107, 229 and $366 \mathrm{~m}$ were used because the diagonal transects did not have the traps near the release site.

\section{Results}

\subsection{Experiments}

The recapture of marked adults at the release point varied from 3.72 to $11.27 \%$ during the early (June) and late (July) season releases (table 1). The recapture of marked males beyond the release point averaged $0.21-$ $1.10 \%$ during the early season release and $1.05-1.97 \%$ for the late season release. The recapture of marked females beyond the release point averaged $0.08-0.13 \%$ during the early season release and $0.16-1.67 \%$ for the late season release. Recapture at release point and beyond the release point was somewhat higher during second release in the north field than during the first release or during both releases of south field (table 1), when the second planting maize was in very attractive growth stage (tassel to silking) during the second release.

In the north field marked males and females that dispersed beyond the release point were recaptured in the same field and also in the south study field during both releases. During the first release a total of 11 males and 2 females were recaptured in the north field. Males were recaptured at $30(n=4)$ and 366 $(n=2) \mathrm{m}$ and females at $61 \mathrm{~m}(n=1)$ from the release point inside the north field. Males from the north field were recaptured in the south field at $152 \mathrm{~m}$ $(n=2), 457,579$ and $671 \mathrm{~m}(n=1$ each) from the release point. One female from the north field was recaptured in the south field at $152 \mathrm{~m}$ from the release

Table 1. Summary of dispersed and recaptured marked European corn borer male and female adults during 1999 and 2001

\begin{tabular}{|c|c|c|c|c|c|c|c|c|c|}
\hline \multirow[b]{2}{*}{ Year } & \multirow[b]{2}{*}{ Release } & \multirow[b]{2}{*}{ Date } & \multirow[b]{2}{*}{$\begin{array}{l}\text { No. pupae } \\
\text { producing } \\
\text { adults }\end{array}$} & \multirow[b]{2}{*}{ Colour } & \multirow[b]{2}{*}{ Gender } & \multicolumn{2}{|c|}{ Number dispersed } & \multicolumn{2}{|c|}{ Percent recapture } \\
\hline & & & & & & $\begin{array}{l}\text { From } \\
\text { release } \\
\text { bucket }\end{array}$ & $\begin{array}{l}\text { Beyond } \\
\text { release } \\
\text { point }\end{array}$ & $\begin{array}{l}\text { From } \\
\text { release } \\
\text { bucket }\end{array}$ & $\begin{array}{c}\text { Beyond } \\
\text { release } \\
\text { point }\end{array}$ \\
\hline \multirow[t]{4}{*}{1999 North field } & \multirow[t]{2}{*}{1} & \multirow[t]{2}{*}{22 June } & \multirow[t]{2}{*}{8288} & \multirow[t]{2}{*}{ Blue } & Male & 5130 & 4360 & 3.72 & 0.21 \\
\hline & & & & & Female & 1424 & 1225 & 3.72 & 0.08 \\
\hline & \multirow[t]{2}{*}{2} & \multirow[t]{2}{*}{13 July } & \multirow[t]{2}{*}{7348} & \multirow[t]{2}{*}{ Blue } & Male & 3105 & 2639 & 11.27 & 1.97 \\
\hline & & & & & Female & 2706 & 2327 & 11.27 & 1.67 \\
\hline \multirow[t]{4}{*}{1999 South field } & \multirow[t]{2}{*}{1} & \multirow[t]{2}{*}{22 June } & \multirow[t]{2}{*}{7187} & \multirow[t]{2}{*}{ Red } & Male & 3955 & 3362 & 5.61 & 1.10 \\
\hline & & & & & Female & 1728 & 1486 & 5.61 & 0.13 \\
\hline & \multirow[t]{2}{*}{2} & \multirow{2}{*}{13 July } & \multirow[t]{2}{*}{6372} & \multirow[t]{2}{*}{ Red } & Male & 2904 & 2468 & 6.88 & 1.05 \\
\hline & & & & & Female & 2135 & 1836 & 6.88 & 0.16 \\
\hline \multirow[t]{6}{*}{2001 Field } & \multirow[t]{2}{*}{1} & \multirow[t]{2}{*}{17 June } & \multirow[t]{2}{*}{13920} & \multirow[t]{2}{*}{ Red } & Male & 4933 & 4802 & 2.65 & 3.60 \\
\hline & & & & & Female & 3312 & 3295 & 0.51 & 0.33 \\
\hline & \multirow[t]{2}{*}{2} & \multirow[t]{2}{*}{11 July } & \multirow[t]{2}{*}{12052} & \multirow[t]{2}{*}{ Red } & Male & 5258 & 5212 & 0.87 & 2.67 \\
\hline & & & & & Female & 3962 & 3939 & 0.58 & 0.61 \\
\hline & \multirow[t]{2}{*}{3} & 5 August & 9360 & Red & Male & 3751 & 3531 & 5.86 & 9.94 \\
\hline & & & & & Female & 2703 & 2537 & 6.14 & 4.37 \\
\hline
\end{tabular}


Table 2. Parameters of the regression models describing the relationship between European corn borer adult catch over distance for 1999 south field using TableCurve 2D

\begin{tabular}{|c|c|c|c|c|c|c|c|}
\hline Model* & $\operatorname{Trap}^{\dagger}$ & Gender $^{\dagger}$ & $a \pm \mathrm{SE}$ & $b \pm \mathrm{SE}$ & $r^{2}$ & $\begin{array}{l}\text { Maximum } \\
\text { attainable } r^{2}\end{array}$ & $\begin{array}{l}\text { Lack of } \\
\text { model fit }\end{array}$ \\
\hline \multicolumn{8}{|c|}{ Marked adults (dispersal from release point to the perimeter trap) - Release: 1} \\
\hline 1 & BL & MF & $1.56 \pm 0.724$ & $317.4370 \pm 2.987$ & 0.99 & 0.99 & 0.21 \\
\hline \multicolumn{8}{|c|}{ Feral adults (dispersal from perimeter trap to the center of field) - Generation: 2} \\
\hline 2 & $\mathrm{P}$ & M & $663.55 \pm 132.00$ & $-0.4633 \pm 0.1360$ & 0.51 & 0.54 & 0.75 \\
\hline 2 & BL & M & $296.68 \pm 37.70$ & $-0.1473 \pm 0.0417$ & 0.49 & 0.73 & 0.09 \\
\hline 2 & BL & $\mathrm{F}$ & $153.37 \pm 29.61$ & $-0.0460 \pm 0.0328$ & 0.13 & 0.60 & 0.05 \\
\hline 2 & $\mathrm{BL}$ & MF & $450.05 \pm 65.94$ & $-0.1934 \pm 0.0730$ & 0.35 & 0.67 & 0.07 \\
\hline 2 & $\mathrm{P}$ and $\mathrm{BL}$ & MF & $656.61 \pm 102.88$ & $-0.1937 \pm 0.1140$ & 0.18 & 0.52 & 0.14 \\
\hline \multicolumn{8}{|c|}{$\begin{array}{l}* \text { Model } 1, \hat{y}=a+b e^{-x} ; \text { Model } 2, \hat{y}=a+b x . \\
+\mathrm{P} \text {, Pheromone; BL, Black light; M, Male; F, Female. } \\
\text { Maximum attainable } r^{2} \text { indicates the maximum amount of variation that any equation fit to the data could explain, allowing for the pure } \\
\text { error in the data (DRAPER and SMITH, 1981). The pure error is the variation in the data that occurs when repeated measurements are made at } \\
\text { identical values of the independent variable. } \\
\S \text { Probability of } 0.05 \text { or below indicates lack of model fit. }\end{array}$} \\
\hline
\end{tabular}

point. During second release a total of 69 males and 42 females were recaptured in the north field. Males were recaptured at all distances from the release point to the perimeter trap at the north end of the field including $30(n=37), 61(n=4), 152(n=6), 366$ $(n=4), 549(n=1)$, and $610 \mathrm{~m}(n=1)$ and females were recaptured at $30(n=37)$ and $61 \mathrm{~m}(n=2)$ from the release point inside the same field. Males from the north field were recaptured in the south field at 274 $(n=4), 366(n=2), 427(n=4), 457(n=3)$ and $823 \mathrm{~m}(n=3)$ from the release point. Females from the north field were recaptured in the south field at 427,457 and $488 \mathrm{~m} \mathrm{(} n=1$ each) from the release point. Only one virgin female was recaptured at $15 \mathrm{~m}$ beyond release point and that was during the first release. The relationship between recapture of marked adults and the dispersal distance from the release point was not analysed due to incomplete trap installation.

In the south field marked males that dispersed beyond the release point were recaptured in the same field and also in the north field and other neighbourhood fields during both releases, but females were recaptured only in the release field. During the first release a total of 45 males and 2 females were recaptured. Males were recaptured at all distances from the release point to the traps at field perimeter including $30(n=12), 61(n=14), 152(n=14)$, and $366 \mathrm{~m}(n=1)$ and both females were recaptured at $61 \mathrm{~m}$ from the release point inside the same field. One male was recaptured in the north field at $853 \mathrm{~m}$ from the release point, and three males were recaptured in another field to the west at $884 \mathrm{~m}$ from the release point. During the second release a total of 30 males and 3 females were recaptured. Males were recaptured at all distances from the release point to the traps at field perimeter including $30(n=13), 61(n=4), 152$ $(n=8)$, and $366 \mathrm{~m}(n=1)$ and all three females were recaptured at $30 \mathrm{~m}$ from the release point inside the same field. Males from the south field were recaptured in the north field at $853(n=2), 309$ and $457 \mathrm{~m}(n=1$ each) from the release point. No virgin female was recaptured beyond the release point during both releases. Only the data set for the combined recaptures of males and females in light traps during the first release were suitable for regression analysis. The relationship between recaptured adults and dispersal distance from the release point could best be explained by the model equation: $\hat{y}=a+b e^{-x}$ (table 2). The relationship can be described as a sudden decline in recapture beyond the release point and the recapture rate stays flat as the distance increases (not figured but same as fig. 3c males).

A total of 895 feral males were captured in the eight pheromone traps installed in the north and south fields during first generation feral adult flight. However, 1256 and 2054 feral males were captured during the second-generation feral adult flight in the north and south fields, respectively. Two of the three neighbourhood fields that were monitored for European corn borer populations turned out to be potential source fields for feral adults (one to the south and one to the west). But there were no significant regressions $(\mathrm{P}>0.05)$ for captures over distance from the source fields. During the second-generation flight the relationship between capture of feral adults and the dispersal distance from perimeter to center of the study field was not analysed for north field due to incomplete trap installation. In the south field during the second-generation flight, a total of 7156 feral males and 1730 feral females were captured. Feral males and females were captured throughout the study field. The relationship between feral adult captures and the dispersal distance from perimeter traps into the field can best be explained by the linear model equation: $\hat{y}=a+b x$ (table 2, fig. 4a). Male captures in the perimeter pheromone traps were surprisingly low and were not included in this analysis. There was a general trend for decline of captures with distance into the field (fig. 4a). There was considerable variability in the light trap data and the slopes were not significant $(\mathrm{P}>0.05)$. Feral females captured during secondgeneration flight were not dissected for mating status. Feral male captures in the pheromone and light traps were not significantly different during the secondgeneration flight $(t=-0.87 ; \mathrm{P}=0.397)$. 

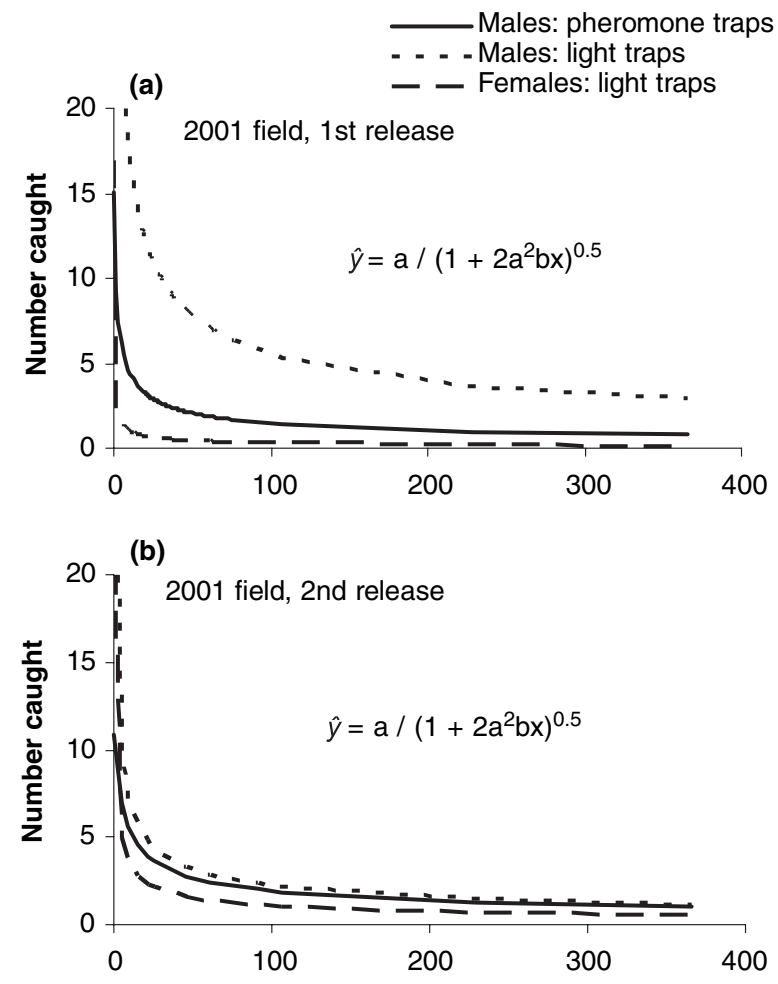

(c)

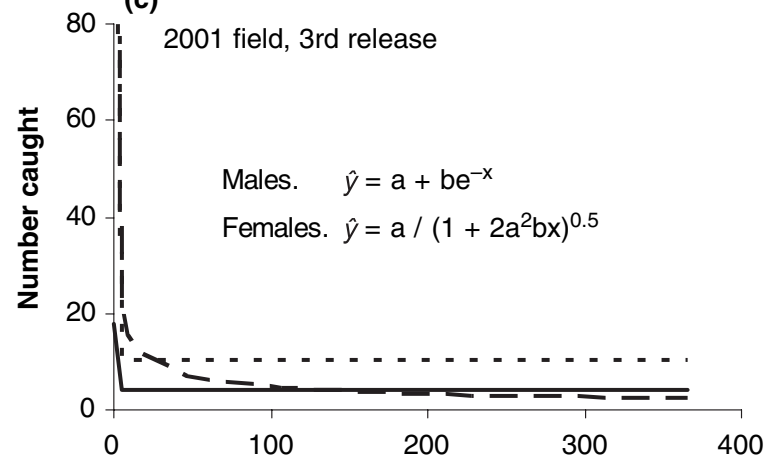

Distance from release point to the perimeter trap $(\mathrm{m})$

Fig. 3. Relationship between the numbers of marked male and female adults of European corn borer recaptured within the Bt-maize fields during the first, second and third releases of 2001 and the distance from the release point in the field center to the perimeter traps

\subsection{Experiments}

The recapture of marked adults at the release point averaged $0.87-5.86 \%$ for the males and $0.51-6.14 \%$ for the females across the three releases (table 1). Recapture beyond the release point averaged 2.67$9.94 \%$ for the males and $0.33-4.37 \%$ for females across the three releases. Recapture was highest during the third release. Neither the daily catches nor the pooled recapture data for males or females at individual trapping sites correlate significantly with temperature, humidity, wind speed or wind direction $(\mathrm{P}>0.05)$.

Marked males and females that dispersed beyond the release point were recaptured at all distances from center to the perimeter of the field during each of the three releases. During the first release a total of

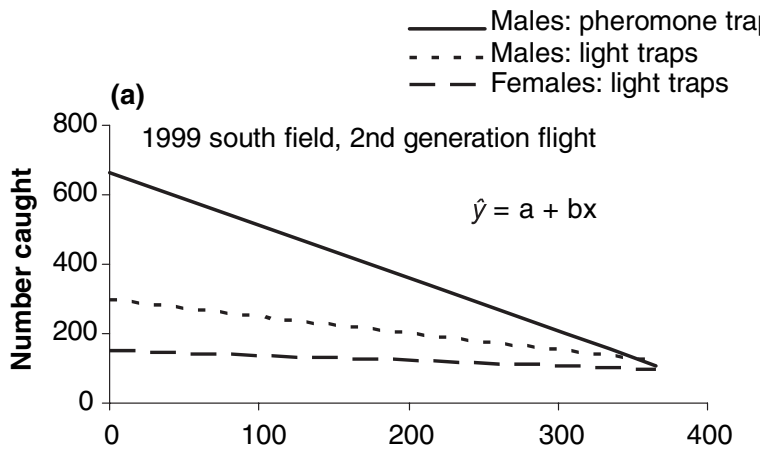

(b)

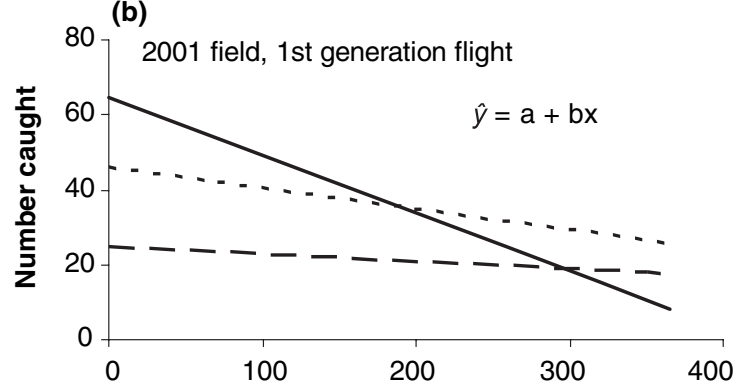

(c)

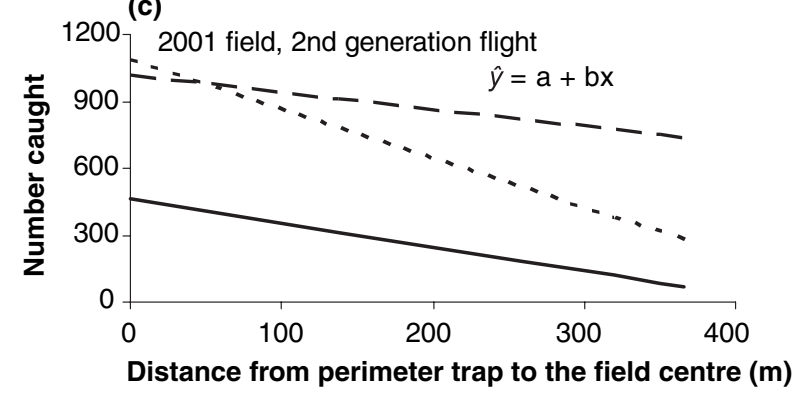

Fig. 4. Relationship between the numbers of feral male and female adults of European corn borer captured within the Bt-maize fields during their first or secondgeneration flights in 1999 and 2001 and the distance from the perimeter traps to the field centre

172 males and 9 females were recaptured. Males and females were recaptured at $15(n=83,3), 46$ $(n=28,2), 107(n=29,1), 229(n=15,2)$ and $366 \mathrm{~m}$ $(n=17,1)$ from the release point within the release field. During second release a total of 138 males and 24 females were recaptured. Males and females were recaptured at $15(n=47,13), 46(n=19,5), 107$ $(n=22,1), 229(n=32,1)$ and $366 \mathrm{~m}(n=18,4)$ from the release point within the release field. During the third release a total of 355 males and 111 females were recaptured. Males and females were recaptured at 15 $(n=73,54), 46(n=65,26), 107(n=64,16), 229$ $(n=77,6)$ and $366 \mathrm{~m}(n=71,9)$ from the release point within the release field. Five males from the third release were recaptured in a neighbouring maize field ca. $800 \mathrm{~m}$ from the release point. No males were recaptured over the native vegetation outside the study field during any of the releases. Of the 307 dissected marked females recaptured during the three releases, $18 \%$ were virgin. The occurrence of the virgin females did not decrease with distance from the release point, but averaged $13-33.33 \%$ (table 3 ). The relationship 
Table 3. Mating status of marked and feral European corn borer females that dispersed between field center and perimeter or vice versa during 2001

\begin{tabular}{|c|c|c|c|c|c|c|c|c|c|c|c|c|c|c|c|c|c|}
\hline \multirow[b]{2}{*}{ Distance $(\mathrm{m})^{*}$} & \multicolumn{4}{|c|}{ Release 1} & \multicolumn{4}{|c|}{ Release 2} & \multicolumn{4}{|c|}{ Release 3} & \multicolumn{5}{|c|}{ Total } \\
\hline & No. Ct. & No. Dis. & M & $\mathrm{V}$ & No. Ct. & No. Dis. & M & $\mathrm{V}$ & No. Ct. & No. Dis. & M & $\mathrm{V}$ & No. Ct. & No. Dis. & M & $\mathrm{V}$ & $\mathrm{V}(\%)$ \\
\hline \multicolumn{18}{|c|}{ Marked females (dispersal from release point to the perimeter trap) } \\
\hline 0 & 17 & 15 & 12 & 3 & 23 & 18 & 13 & 5 & 166 & 143 & 121 & 22 & 206 & 176 & 146 & 30 & 17.05 \\
\hline 15 & 3 & 3 & 3 & 0 & 13 & 12 & 8 & 4 & 54 & 51 & 43 & 8 & 70 & 66 & 54 & 12 & 18.18 \\
\hline 46 & 2 & 1 & 1 & 0 & 5 & 5 & 4 & 1 & 26 & 24 & 21 & 3 & 33 & 30 & 26 & 4 & 13.33 \\
\hline 107 & 1 & 1 & 1 & 0 & 1 & 1 & 1 & 0 & 16 & 13 & 10 & 3 & 18 & 15 & 12 & 3 & 20.00 \\
\hline 229 & 2 & 2 & 2 & 0 & 1 & 1 & 1 & 0 & 6 & 6 & 3 & 3 & 9 & 9 & 6 & 3 & 33.33 \\
\hline 366 & 1 & 1 & 1 & 0 & 4 & 2 & 2 & 0 & 9 & 8 & 6 & 2 & 14 & 11 & 9 & 2 & 18.18 \\
\hline \multicolumn{18}{|c|}{$\begin{array}{l}\text { Feral females (dispersal from perimeter trap to the center of field) } \\
\text { Generation } 1\end{array}$} \\
\hline Distance $(\mathrm{m})^{\dagger}$ & No. Ct. & No. Dis. & M & V & No. $\mathrm{Ct}$ & No. Dis. & M & V & & & & & & & & & \\
\hline 0 & 114 & 88 & 78 & 10 & 2116 & 105 & 102 & 3 & & & & & 2230 & 193 & 180 & 13 & 6.74 \\
\hline 137 & 76 & 57 & 52 & 5 & 1425 & 152 & 146 & 6 & & & & & 1501 & 209 & 198 & 11 & 5.26 \\
\hline 259 & 60 & 49 & 46 & 3 & 1856 & 154 & 150 & 4 & & & & & 1916 & 203 & 196 & 7 & 3.45 \\
\hline 320 & 68 & 51 & 45 & 6 & 1320 & 66 & 66 & 0 & & & & & 1388 & 117 & 111 & 6 & 5.13 \\
\hline 351 & 72 & 60 & 49 & 11 & 579 & 70 & 68 & 2 & & & & & 651 & 130 & 117 & 13 & 10.00 \\
\hline 366 & 42 & 37 & 27 & 10 & 150 & 28 & 25 & 3 & & & & & 192 & 65 & 52 & 13 & 20.00 \\
\hline
\end{tabular}

between male and female recaptures during first and second releases and the dispersal distance could be explained with a negative exponential decay model equation $\hat{y}=a /\left(1+2 a^{2} b x\right)^{0.5}$ (table 4$)$. There was a smooth decline in recapture with increasing distance from the release point to the perimeter of the field (fig. 3a,b). For the third release, this model worked for variables that included females, but male variables were better explained by the model equation $\hat{y}=a+b e^{-x}$ (table 4). So for males there was a precipitous decline in recapture beyond the release point and the recapture rate stayed flat as the distance increased (fig. 3c). Based on the dispersal equations described for released marked European corn borers the radius of a circle that included $90-99 \%$ of the recaptured insects averaged $297-362 \mathrm{~m}$ (table 5). The radius of the circle that included $50 \%$ of the recaptured insects averaged only 93-107 m. Very few marked European corn borers were recaptured beyond $300 \mathrm{~m}$ from the release point. Marked male recapture on the main transects was significantly higher in light traps than in pheromone traps during the first release $(S=64.5 ; \quad \mathrm{P}=0.001)$ and in the third release $(S=89.5 ; \mathrm{P}=0.001)$, but it was not significantly different during the second release $(S=7 ; \mathrm{P}=0.733)$. The marked male recaptures in pheromone traps installed alone or together with light traps were not significantly different for any of the three releases, first release $(t=-1.41 ; \mathrm{P}=0.252)$, second release $(t=-2.47 ; \mathrm{P}=0.090)$, or third release $(t=-0.28$; $\mathrm{P}=0.798)$.

A total of 1213 feral males and 432 feral females were captured in the study field during first generation flight, and 25242 feral males and 17828 feral females were captured during second-generation flight. For both generation flights the relationship between feral adults and distance from the perimeter traps into the field could best be explained with a linear model $\hat{y}=a+b x$ (table 4; fig. 4b,c). During the first generation flight male captures in pheromone traps at the perimeter were much lower than catches in traps that were farther into the field, so the perimeter trap catches were not included in the regression analysis for that data set. As in the 1999 study, there was a lot of variability in the feral adult catch for both generations and there were no trends in the data that could indicate any relationship other than a linear one. Although the model was a good fit $(\mathrm{P}>0.05)$ for all the catch variables for the first flight, the slopes were rather flat and suggest a rather uniform adult distribution (table 4; fig. 4b). The model was not a good fit $(\mathrm{P}<0.05)$ for female captures in light traps during the second generation and the slopes were flat suggesting a rather uniform distribution of adults (table 4; fig. 4c). Virgin females constituted $7 \%$ of the 917 dissected females, and the ratio of virgin females was relatively constant from 0 to $320 \mathrm{~m}$ into the field (3-20\%) (table 3). Feral male captures were not significantly different between pheromone and light traps on the main transects during the first generation flight $(t=1.31$; $\mathrm{P}=0.205)$, but they were significantly higher in light traps than in pheromone traps during the secondgeneration flight $(t=7.54 ; \mathrm{P}=0.001)$. Feral male captures were significantly higher $(t=3.20 ; \mathrm{P}=0.05)$ in pheromone traps placed together with light traps than in the pheromone traps placed alone during the first generation flight, but they were significantly higher $(t=-7.41 ; \mathrm{P}=0.005)$ in the pheromone traps placed alone than in traps that were placed together with light traps during the secondgeneration flight. 
Table 4. Parameters of the regression models describing the relationship between European corn borer adult catch over distance for 2001 using TableCurve 2D

\begin{tabular}{|c|c|c|c|c|c|c|c|c|}
\hline & Model* & $\operatorname{Trap}^{\dagger}$ & Gender $^{\dagger}$ & $a \pm \mathrm{SE}$ & $b \pm \mathrm{SE}$ & $r^{2}$ & $\begin{array}{l}\text { Maximum } \\
\text { attainable } r^{2}\end{array}$ & $\begin{array}{l}\text { Lack of } \\
\text { model fit }\end{array}$ \\
\hline \multicolumn{9}{|c|}{ Marked adults (dispersal from release point to the perimeter trap) } \\
\hline \multirow[t]{5}{*}{ Release: 1} & 3 & $\mathrm{P}$ & M & $15.02 \pm 1.90$ & $0.0007 \pm 0.0003$ & 0.74 & 0.75 & 0.96 \\
\hline & 3 & $\mathrm{BL}$ & M & $116.02 \pm 4.06$ & $0.00005 \pm 0.00001$ & 0.97 & 0.98 & 0.20 \\
\hline & 3 & BL & $\mathrm{F}$ & $17.00 \pm 0.59$ & $0.0145 \pm 0.0082$ & 0.98 & 0.98 & 0.91 \\
\hline & 3 & $\mathrm{BL}$ & MF & $133.01 \pm 4.17$ & $0.00005 \pm 0.00001$ & 0.98 & 0.99 & 0.25 \\
\hline & 3 & $\mathrm{P}$ and $\mathrm{BL}$ & MF & $148.02 \pm 4.41$ & $0.00003 \pm 0.000006$ & 0.98 & 0.99 & 0.17 \\
\hline \multirow{5}{*}{ Release: 2} & 3 & $\mathrm{P}$ & M & $10.82 \pm 3.28$ & $0.0004 \pm 0.0003$ & 0.29 & 0.34 & 0.90 \\
\hline & 3 & BL & M & $35.03 \pm 3.38$ & $0.0003 \pm 0.0001$ & 0.83 & 0.89 & 0.15 \\
\hline & 3 & $\mathrm{BL}$ & $\mathrm{F}$ & $23.00 \pm 1.23$ & $0.0013 \pm 0.0004$ & 0.94 & 0.95 & 0.50 \\
\hline & 3 & BL & MF & $58.02 \pm 3.77$ & $0.0001 \pm 0.00003$ & 0.92 & 0.95 & 0.06 \\
\hline & 3 & $\mathrm{P}$ and $\mathrm{BL}$ & MF & $69.03 \pm 4.45$ & $0.00005 \pm 0.00001$ & 0.91 & 0.93 & 0.41 \\
\hline \multirow[t]{5}{*}{ Release: 3} & 1 & $\mathrm{P}$ & M & $4.35 \pm 0.59$ & $13.6500 \pm 2.6860$ & 0.58 & 0.58 & 0.99 \\
\hline & 1 & BL & M & $10.30 \pm 1.25$ & $191.7000 \pm 5.7496$ & 0.98 & 0.99 & 0.33 \\
\hline & 3 & $\mathrm{BL}$ & $\mathrm{F}$ & $166.00 \pm 2.66$ & $0.00007 \pm 0.00001$ & 0.99 & 0.99 & 0.62 \\
\hline & 3 & BL & MF & $368.00 \pm 7.64$ & $0.00001 \pm 0.000002$ & 0.99 & 0.99 & 0.36 \\
\hline & 3 & $\mathrm{P}$ and $\mathrm{BL}$ & MF & $385.99 \pm 8.74$ & $0.000007 \pm 0.000001$ & 0.99 & 0.99 & 0.06 \\
\hline \multicolumn{9}{|c|}{ Feral adults (dispersal from perimeter trap to the center of field) } \\
\hline \multirow[t]{5}{*}{ Flight: 1} & 2 & $\mathrm{P}$ & M & $64.68 \pm 16.37$ & $-0.0471 \pm 0.0175$ & 0.33 & 0.35 & 0.94 \\
\hline & 2 & BL & M & $46.05 \pm 11.22$ & $-0.0168 \pm 0.0133$ & 0.08 & 0.29 & 0.38 \\
\hline & 2 & $\mathrm{BL}$ & $\mathrm{F}$ & $24.89 \pm 7.41$ & $-0.0060 \pm 0.0088$ & 0.02 & 0.16 & 0.67 \\
\hline & 2 & $\mathrm{BL}$ & MF & $70.94 \pm 18.17$ & $-0.0227 \pm 0.0216$ & 0.06 & 0.24 & 0.47 \\
\hline & 2 & $\mathrm{P}$ and $\mathrm{BL}$ & MF & $104.37 \pm 15.28$ & $-0.0379 \pm 0.0182$ & 0.19 & 0.39 & 0.33 \\
\hline \multirow[t]{5}{*}{ Flight: 2} & 2 & $\mathrm{P}$ & M & $462.06 \pm 46.67$ & $-0.3275 \pm 0.0555$ & 0.65 & 0.67 & 0.90 \\
\hline & 2 & BL & M & $1083.49 \pm 90.96$ & $-0.6677 \pm 0.1082$ & 0.67 & 0.77 & 0.20 \\
\hline & 2 & BL & $\mathrm{F}$ & $1015.57 \pm 102.36$ & $-0.2302 \pm 0.1218$ & 0.16 & 0.55 & 0.04 \\
\hline & 2 & BL & MF & $2099.07 \pm 186.66$ & $-0.8979 \pm 0.2221$ & 0.46 & 0.69 & 0.07 \\
\hline & 2 & $\mathrm{P}$ and $\mathrm{BL}$ & MF & $2561.09 \pm 215.54$ & $-1.2254 \pm 0.2564$ & 0.55 & 0.71 & 0.12 \\
\hline \multicolumn{9}{|c|}{$\begin{array}{l}\text { * Model 1, } \hat{y}=a+b e^{-x} \text {; Model 2, } \hat{y}=a+b x \text {; Model 3, } \hat{y}=a /\left(1+2 a^{2} b x\right)^{0.5} \text {. } \\
\text { P, Pheromone; BL, Black light; M, Male; F, Female. } \\
\text { Maximum attainable } r^{2} \text { indicates the maximum amount of variation that any equation fit to the data could explain, allowing for the pure } \\
\text { error in the data (DRAPER and SMITH, 1981). The pure error is the variation in the data that occurs when repeated measurements are made at } \\
\text { identical values of the independent variable. } \\
\text { \$ Probability of } 0.05 \text { or below indicates lack of model fit. }\end{array}$} \\
\hline
\end{tabular}

Table 5. Estimated dispersal ranges of marked European corn borer adults based on models for recapture distance relationship during three releases of 2001

\begin{tabular}{|c|c|c|c|c|c|c|c|}
\hline \multirow[b]{2}{*}{ Release } & \multirow[b]{2}{*}{ Model* } & \multicolumn{2}{|c|}{ Model parameter } & \multicolumn{4}{|c|}{ Estimated dispersal ranges $(\mathrm{m})^{\dagger}$} \\
\hline & & $a$ & $b$ & $50 \%$ & $90 \%$ & $95 \%$ & $99 \%$ \\
\hline \multicolumn{8}{|c|}{ Males from pheromone traps } \\
\hline 1 & 3 & 15.02 & 0.0007 & 101 & 300 & 332 & 359 \\
\hline 2 & 3 & 10.82 & 0.0004 & 107 & 302 & 333 & 359 \\
\hline 3 & 1 & 4.35 & 13.65 & 183 & 329 & 347 & 362 \\
\hline \multicolumn{8}{|c|}{ Males from light traps } \\
\hline 1 & 3 & 116.02 & 0.00005 & 96 & 298 & 331 & 359 \\
\hline 2 & 3 & 35.03 & 0.0003 & 98 & 299 & 331 & 359 \\
\hline 3 & 1 & 10.3 & 191.7 & 180 & 329 & 347 & 362 \\
\hline \multicolumn{8}{|c|}{ Females from light traps } \\
\hline 1 & 3 & 17 & 0.0145 & 93 & 298 & 331 & 359 \\
\hline 2 & 3 & 23 & 0.0013 & 96 & 298 & 331 & 359 \\
\hline 3 & 3 & 166 & 0.00007 & 94 & 297 & 331 & 358 \\
\hline
\end{tabular}

\section{Discussion}

In mark-release-recapture experiments marked insects are often released at high densities from a single point (Plant and Cunningham, 1991). This can expose the insects to unusually high densities at the release site, which can affect the dispersal behaviour of study insects. Transportation from the laboratory to the field can also expose the insects to sudden changes in environmental conditions and can cause unnatural dispersal.
Therefore, we chose to place pupae at the release sites so that adults could emerge and disperse as they eclosed over several days.

The first release was made in pre-reproductive stage maize, while the second and third releases were made in post-reproductive maize. There is no obvious explanation for the difference in the recapture rate of second and third releases. However, during the second release, recapture also was low at the release point. Perhaps the 
actual adult dispersal was higher during the second release and populations dispersed out of the field more quickly. The high recapture rate in the north field during the second release in 1999 appeared to be associated with the very attractive stage (silk-to-milk) of the replanted maize compared with the more mature maize in the rest of the neighbourhood. Despite the smaller number of released insects the recapture rate was higher for both males and females during the third release compared with the first two releases of 2001. In the Iowa dispersal study, the recapture of marked males was higher in late season tall, mature maize than in early season short vegetative maize (SHOwERs et al., 2001). European corn borers are reported to disperse many meters or kilometres before settling again. However, in those studies large numbers of caged adults were transported to an open area surrounded by mixed vegetation and insects were allowed to disperse all at once at dusk. The nearest traps were installed at $200 \mathrm{~m}$ from the release point.

The rate of male capture in light traps and pheromone traps placed $2 \mathrm{~m}$ apart appeared to be independent. For most data sets there was no difference in male capture for pheromone traps sited alone or with light traps. This means that there was no interference or competition between those traps. In a preliminary study there also was no difference in the capture of feral European corn borer adults in light traps $(15 \mathrm{~W}$ bulbs) placed $1.5,3$ or $5 \mathrm{~m}$ apart (J.A.Q., unpublished data). This suggests that the distance between light traps in this study $(15 \mathrm{~m})$ did not cause interference between the light traps. BAKER and SADOvY (1978) reported that captures of the yellow underwing, Noctua pronuba, and the heart and dart, Agrotis exclamationis, declined only for light traps $(125 \mathrm{~W}$ bulbs) that were 1-3 $\mathrm{m}$ apart. This suggested that the area of influence for the light traps was $1-3 \mathrm{~m}$. We are not aware of any reports on the area influence for European corn borer pheromone traps. Male recapture rate appeared to be slightly higher in light traps than in pheromone traps where they were sited together.

Distance from the release site was the only variable that could be correlated with dispersal. Recaptures of marked adults were similar in all directions. The study fields were center pivot irrigated so the conditions must have been rather uniform for dispersing adults in different parts of the field. Average daily wind direction and wind speed did not correlate with recaptures. However, interpreting the effects of wind direction, wind speed, temperature or humidity on recaptures is questionable since we did not have specific measurements for the time of day the insects were active. Also the winds at ground level can be turbulent, and wind direction on the surface and within the plant canopy may not correlate with the above plant canopy winds (JERMY et al., 1988). The effect of wind may be more important when insects are flying between maize fields and may have played a role in the dispersal of feral populations from refuge sources into the study fields. We did not have enough traps installed outside the release field to adequately evaluate field-to-field movement. We were probably capturing insects that were flying within the maize canopy.
One-dimensional spatial dispersal can best be explained with a mathematical equation (PLANT and Cunningham, 1991). The two different mathematical models required to explain the dispersal data for released insects and for feral insects were interesting. One explanation might be that the linear distribution of feral insects may represent the extended tail of the exponential decay equation when it gets beyond $100-200 \mathrm{~m}$ from the source field. In this case, there must be a number of fields in the neighbourhood producing relatively large numbers of ferel insects, because the numbers were relatively high and they appeared to be entering the field from all directions. The neighbourhood maize fields would not be expected to produce large numbers of corn borers because the fields were treated with insecticides to keep insect damage below economic injury levels. In 1999 we were aware of several non-Bt-maize fields near the study fields. In 2001 we were aware of only one non-Bt-maize field within $1000 \mathrm{~m}$ of the study field.

The two different mathematical models required to explain the dispersal data may mean that the released marked insects and the feral insects represent two subpopulations or age groups. Other insects such as the pink bollworm, Pectinophora gossypiella (Saunders), (TABASHNik et al., 1999) and western corn rootworm, Diabrotica virgifera virgifera LeConte, (CoATs et al., 1986) are reported to have some individuals that are long distance dispersers and others that are short distance dispersers. This suggests that one group of European corn borers may settle down within the release field, and the other group leaves the field immediately upon eclosion. In Iowa, SHowers et al. (2001) reported that released males did not land until they had flown for several meters or kilometres. In this study, adults that dispersed beyond the natal field would not have been subject to recapture in the traps installed in the study field. The low recapture rate for marked European corn borer in this study could indicate that many of the marked insects were not staying in the study field and were not available for capture in the traps we installed. The relatively uniform distribution of marked adults across the release field suggests that corn borers have the potential to disperse extensively.

The availability of favourable humidity in irrigated maize fields would appear to encourage corn borers to stay in the natal field or to disperse to other irrigated maize fields. This agrees with the observation that no males were recaptured over the native vegetation outside the 2001 field, even when males were recaptured in the neighbouring maize field. Dispersal between the two study fields of 1999 suggests that males dispersed out of the release field more frequently than did females. These results do not readily fit the 'general model of European corn borer dispersal' from Iowa (SHOwERS et al., 1980). However, they are similar to the results reported from Nebraska (HunT et al., 2001). In this study the dry native vegetation areas between the study fields seemed to be barriers for the dye-marked insects within the fields. However, these areas did not appear to inhibit the dispersal of feral populations. European corn borers were not attracted to pheromone traps 
located in the native vegetation outside the irrigated fields and action sites were not observed in these areas.

The large number of feral male and female captures throughout the study fields suggests that long distance dispersers were present and that there were quite a few of them. There was only a slight decline in the occurrence of males or females across the distance into the study fields indicating they may have flown long distances from their natal fields. The distance from potential source fields was at least $587-1387 \mathrm{~m}$. The distribution of feral insects was best explained with a nearly flat linear model. There is no evidence that the small non-Bt nursery block in the field center, that was intended for producing $\mathrm{Rb} / \mathrm{Cs}$ marked insects, produced any non-dye-marked or 'feral insects' even during the second flight. The distribution of non-dyemarked or feral insects was relatively uniform throughout the study fields.

There was no evidence that the pheromone traps attracted feral males into the study fields. The pheromone traps would have attracted both marked and feral males flying near the study fields. We would have expected a higher recapture rate for the dye-marked males if males had been attracted into the study field. In addition, the pheromone traps located outside the fields did not attract any marked males.

Dispersal of corn borers plays an important role in the IRM strategy for corn borers in Bt-maize. Based on standard assumptions of completely random dispersal for males and females, resistance develops in the European corn borer within 30 years (GusE et al., 2002). Our data suggest that male dispersal may be as extensive as assumed in the model, but that female dispersal may be less extensive than assumed. Fewer females than males were recaptured in the markreleased populations and fewer feral females than males were captured in the study fields in light traps. This suggests that females would lay more eggs in the natal field than assumed in the IRM models. This would tend to allow the susceptible insects to better maintain their populations in the refuge plantings. It would also tend to confine any resistant genes to the natal Bt-maize field where the next generation would be more likely to be exposed to high-dose Bt-maize. Both of these effects would tend to slow down the development of resistance making the IRM strategy more robust. However, the extent of pre-copulatory dispersal of corn borer females and the location of mating activity are important variables that still need to be better understood, particularly in the irrigated corn production situation. These variables could affect IRM in these areas.

The current IRM plan for Bt-maize assumes that surviving females in a Bt-maize field will mate with susceptible males that disperse from refuge plantings in the neighbourhood. In the current studies, a significant proportion of females remained virgin (18-20\%), and this percentage did not appear to decrease with distance. Even feral populations had $>20 \%$ virgin females. Many of the dye-marked females must have mated near the release point before dispersing, because there did not seem to be a decrease in virgin female occurrence with distance from the release point. It is difficult to know whether the feral females mated in their natal field or in the new field. The reason for the high frequency of virgin females is still mysterious. Insect flight often becomes more local and presumably less dispersive as females age and the need to lay eggs increases (Johnson, 1963). Since there were no black light traps outside the study fields it was not possible to keep track of female movement outside the study fields. However, in the two 1999 study fields only a few females from the north study field were recaptured in the other study field.

It is not entirely clear how to use this dispersal data to select the maximum separation distance that would be needed between $\mathrm{Bt}$ and non-Bt refuge fields that would allow adequate mixing of the two populations to support the high-dose-refuge IRM strategy. Mo et al. (2003) suggest a maximum separation of $<50 \mathrm{~m}$ for cauliflower and broccoli fields based on the average dispersal distances of $13-35 \mathrm{~m}$ recorded for the diamondback moth, Plutella xylostella (L). They also calculate that the radius of an ellipse that would include $99 \%$ of the moths would be about $200 \mathrm{~m}$.

The current resistance management program for European corn borers in Bt-maize requires that the non-Bt-maize refuge field be within $800 \mathrm{~m}$ ( 0.5 mile $)$ of the Bt-maize field. In this study, the radius of the circle that included 50 and $99 \%$ of European corn borers was about 100 and $350 \mathrm{~m}$, respectively. This is considerably less than the $800 \mathrm{~m}$ currently recommended as the maximum separation for resistance management of this insect. However, it should be noted that the distribution of feral European corn borers was more extensive than that of dye-marked insects (flat and linear vs. rapid decline in an exponential decay distribution). The actual dispersal between fields may well be considerably greater than the data for dye-marked insects suggest. It is not clear if the dispersal recorded in this study is extensive enough to support the current resistance management strategy for corn borers. There appears to be some dispersal of corn borers from the non-transgenic 'refuge' fields into the transgenic fields that would allow for some genetic mixing of the populations. However, the adult dispersal could be different in different regions depending upon agronomic and climatic conditions. Additional studies will be needed to better understand any age related changes in moth dispersal behavior of $O$. nubilalis. If very many corn borers engage in long distance dispersal during the pre-oviposition period then the distance between Bt-maize fields and refuge fields will not need to be quite as restrictive as it is now.

\section{Acknowledgements}

We thank Rick Helmich at USDA-ARS Corn Insects and Crop Genetics Research Unit Ames IA for providing the marked pupae, Jose Guzman, Art Nonhof and other daily wage staff for help with field studies and P.E. Sloderbeck for reviewing the manuscript. This article is Contribution No. 05-138-J from the Kansas Agricultural Experiment Station and represents work sponsored by F-205, NC-205, Monsanto Co., and AgrEvo Co. Voucher specimens No. 149 are located in the Kansas State University Museum of Entomological and Prairie Arthropod Research. 


\section{References}

BAKER, R. R.; SADOvy, Y., 1978: The distance and nature of light trap response of moths. Nature 276, 818-821.

Calvin, D. D.; Van Duyn, J. W., 1999: European corn borer. In: Handbook of Corn Insects Ed. by StefFey, K. L.; Rice, M. E.; All, J.; Andow, D. A.; Gray, M. E.; Van Duyn, J. W. Lanham, MD: Entomological Society of America, 78-82.

Conts, S. A.; Tollefson, J. J.; Mutchmor, J. A., 1986: Study of migratory flight in the western corn rootworm (Coleoptera: Chrysomelidae). Environ. Entomol. 15, 1-6.

Derozari, M. B.; Showers, W. B.; Shaw, R. H., 1977: Environment and sexual activity of the European corn borer. Environ. Entomol. 6, 657-665.

Draper, N.; Smith, R. H., 1981: Applied Regression Analysis, 2nd edn. New York: Wiley. 709pp.

Gould, F., 1994: Potential and problems with high-dose strategies for pesticidal engineered crops. Biocontrol Sci. Tech. 4, 451-461.

Guse, C. A.; Onstad, D. W.; Buschman, L. L.; Porter, P.; Higgins, R. A.; Sloderbeck, P. E.; Cronholm, G. B.; Peairs, F. B., 2002: Modeling the development of resistance by stalk boring Lepidoptera (Crambidae) in areas with irrigated transgenic corn. Environ. Entomol. 31, 676-685.

Huang, F.; Buschman, L. L.; Higgins, R. A.; McGaughey, W. H., 1999: Inheritance of resistance to Bacillus thuringiensis toxin (Dipel ES) in the European corn borer. Science 284, 965-967.

Hunt, T. E.; Hellmich, R. L.; Dyer, J. M.; Higley, L. G.; Wiткошsкi, J. F., 2000: Oil-soluble dyes for marking European corn borer (Lepidoptera: Crambidae). J. Entomol. Sci. 35, 338-341.

Hunt, T. E.; Higley, L. G.; Witkowski, J. F.; Young, L. J.; Hellmich, R. L., 2001: Dispersal of adult European corn borer (Lepidoptera: Crambidae) within and proximal to irrigated and non-irrigated corn. J. Econ. Entomol. 94, 1369-1377.

Jandel Scientific, 1996: TableCurve 2D Automated Curve Fitting And Equation Discovery, Version 4. San Rafael, CA: Jandel Scientific.

Jermy, T.; Szentesi, A.; Horvath, J., 1988: Host plant finding in phytophagous insects: the case of the Colorado potato beetle. Entomol. Exp. Appl. 49, 83-98.

Johnson, C. G., 1963: Physiological factors in insect migration by flight. Nature 198, 423-427.

Koziel, M. G.; Beland, G. L.; Bowman, C.; Carrozzi, N. B.; Crenshaw, R.; Crossland, L.; Dawson, L.; Desai, N.; Hill, M.; Kadwell, S.; Launis, K.; Lewis, K.; Maddox, D. McPherson, K.; Meghi, M. R.; Merlin, E.; Rhodes, R.; Warren, G. W.; Wright, M.; Evola, S. V., 1993: Field performance of elite transgenic maize plants expressing an insecticidal protein derived from Bacillus thuringiensis. Bio./Technol. 11, 194-200.

LeE, D. A., 1988: Moth density and oviposition patterns of the European corn borer, Ostrinia nubilalis (Lepidoptera: Pyralidae), in Alberta. Environ. Entomol. 17, 220-224.

Lewis, L. C.; LynCH, R. E., 1969: Rearing the European corn borer on diets containing corn leaf and wheat germ. Iowa State J. Sci. 44, 9-14

Mason, C. E.; Rice, M. E.; Calvin, D. D.; Van Duyn, J. W.; Showers, W. B.; Hutchinson, W. D.; Witkowski, J. F.; Higgins, R. A.; Onstad, W. D.; Dively, G. P., 1996 European Corn Borer Ecology And Management. Ames: Iowa State University. North Central Regional Extension Publication. 327. 57pp.

Mo, J.; Baker, G.; Keller, M.; Roush, R., 2003: Local dispersal of the diamondback moth (Plutella xylostella (L.)) (Lepidoptera: Plutellidae). Environ. Entomol. 32, 71-79.
Onstad, D. W.; Guse, C. A.; Porter, P.; Buschman, L. L.; Higgins, R. A.; Sloderbeck, P. E.; Peairs, F. B.; Cronholm, G. B., 2002: Modeling the development of resistance by stalk boring Lepidoptera (Crambidae) in areas with transgenic corn and frequent insecticide use. Environ. Entomol. 31, 1033-1043.

Ostlie, K. R.; Hutchison, W. D.; Hellmich, R. L., 1997: Bt-corn and European corn borer. (Ed) St Paul, MN: North Central Reg. Ext. Publ. Univ. Minn. Ext. Serv.

Plant, R. E.; Cunningham, R. T., 1991: Analyses of the dispersal of sterile Mediterranean fruit flies (Diptera: Tephritidae) released from a point source. Environ. Entomol. 20, 1493-1503.

Royer, L.; McNeIL, J. N., 1991: Changes in calling behavior and mating success in the European corn borer (Ostrinia nubilalis) caused by relative humidity. Entomol. Exp. Appl. 61, 131-138.

SAS Institute, 1999-2000: The SAS System for Windows Release 8.01. Cary, NC, USA: SAS Institute.

Shelton, A. M.; TAng, J. D.; Roush, R. T.; Metz, T. D.; Earle, E. D., 2000: Field tests on managing resistance to Btengineered plants. Nature Biotechnol. 18, 339-342.

Showers, W. B.; Reed, G. L.; Oloumi-SAdeghi, H., 1974: European corn borer: attraction of males to synthetic lure and to females of different strains. Environ. Entomol. 3, $51-58$.

Showers, W. B.; Berry, E. C.; Kaster, L. V., 1980: Management of 2 nd generation European corn borer by controlling moths outside the corn field. J. Econ. Entomol. 73, 88-91.

Showers, W. B.; Hellmich, R. L.; Derrick-Robinson, M. E.; Hendrix, W. H. 2001: Aggregation and dispersal behavior of marked and released European corn borer (Lepidoptera: Crambidae) adults. Environ. Entomol. 30, 700-710.

Snedecor, G. W.; Cochran, W. G., 1989: Statistical Methods, 8th edn. Ames: Iowa State University Press. 503pp.

Sparks, A. N., 1963: Preliminary studies of factors influencing mating of the European corn borer. Proc. N. Centr. Br. Entomol. Soc. Am. 18, 95.

Systat Software Inc., 2002: TableCurve 2D. http://www. systat.com/products/TableCurve2D/resources/?sec $=1008$.

Tabashnik, B. E.; Patin, A. L.; Dennehy, T. J.; Liu, Y-B. Miller, E.; Staten, R. T., 1999: Dispersal of pink bollworm (Lepidoptera: Gelechiidae) males in transgenic cotton that produces a Bacillus thuringiensis toxin. J. Econ. Entomol. 92, 772-780.

Turchin, P.; Thoeny, W. T., 1993: Quantifying dispersal of southern pine beetles with mark-recapture experiments and a diffusion model. Ecol. Appl. 3, 187-198.

US EPA, 1998: Final Report of the FIFRA Scientific Advisory Panel Subpanel on Bacillus thuringiensis (Bt) Plant-pesticides and Resistance Management. http:// www.epa.gov/scipoly/sap/1998/february/finalfeb.pdf.

US EPA, 2001: Bacillus Thuringiensis Plant-Incorporated Protectants. Biopesticides Registration Action Document. http://www.epa.gov/pesticides/biopesticides/reds/ brad_Bt_pip2.htm.

Webster, R. P.; Cardé, R. T., 1982: Influence of relative humidity on calling behavior of the female European corn borer moth (Ostrinia nubilalis). Entomol. Exp. Appl. 32, 181-185.

Author's address: Lawrent L. Buschman (corresponding author), K-State University Southwest Research and Extension Center, 4500 E. Mary St., Garden City, KS 67846-6028, USA. E-mail: lbuschma@ksu.edu 